\title{
MiR-23a modulates $X$-linked inhibitor of apoptosis-mediated autophagy in human luminal breast cancer cell lines
}

\author{
Ping Chen ${ }^{1,2, *}$, Yin-Huan $\mathrm{He}^{2, *}$, Xing Huang ${ }^{3, *}$, Si-Qi Tao ${ }^{2, *}$, Xiao-Nan Wang ${ }^{2}$, Hong \\ Yan ${ }^{2}$, Ke-Shuo Ding ${ }^{2}$, Peter E. Lobie ${ }^{4,5}$, Wen-Yong $\mathbf{W u}^{6}$ and Zheng-Sheng $\mathbf{W u}^{2}$ \\ 'Li Shui People's Hospital, Nanjing, Jiangsu, China \\ ${ }^{2}$ Department of Pathology, Anhui Medical University, Hefei, Anhui, China \\ ${ }^{3}$ Institute of Life Sciences, Key Laboratory of Developmental Genes and Human Disease, Southeast University, Nanjing, \\ China \\ ${ }^{4}$ Cancer Science Institute of Singapore and Department of Pharmacology, National University of Singapore, Singapore, \\ Singapore \\ ${ }^{5}$ Tsinghua Berkeley Shenzhen Institute, Tsinghua University Graduate School at Shenzhen, Shenzhen, Guangdong, China \\ ${ }^{6}$ Department of General Surgery, The First Affiliated Hospital of Anhui Medical University, Hefei, Anhui, China \\ *These authors contributed equally to this work
}

Correspondence to: Zheng-Sheng Wu, email: woozson@yahoo.com Wen-Yong Wu, email: ayfywwy@sina.cn

Keywords: miR-23a, autophagy, XIAP, breast cancer

Received: April 04, $2017 \quad$ Accepted: September 03, $2017 \quad$ Published: September 19, 2017

Copyright: Chen et al. This is an open-access article distributed under the terms of the Creative Commons Attribution License 3.0 (CC BY 3.0), which permits unrestricted use, distribution, and reproduction in any medium, provided the original author and source are credited.

\section{ABSTRACT}

Autophagy is a conserved multi-step lysosomal process that is induced by diverse stimuli including cellular nutrient deficiency. X-linked inhibitor of apoptosis (XIAP) promotes cell survival and recently has been demonstrated to suppress autophagy. Herein, we examined regulation of XIAP-mediated autophagy in breast cancer cells and determined the underlying molecular mechanism. To investigate this process, autophagy of breast cancer cells was induced by Earle's balanced salt solution (EBSS). We observed discordant expression of XIAP mRNA and protein in the autophagic process induced by EBSS, suggesting XIAP may be regulated at a post-transcriptional level. By scanning several miRNAs potentially targeting XIAP, we observed that forced expression of $m i R-23 a$ significantly decreased the expression of XIAP and promoted autophagy, wherever down-regulation of miR-23a increased XIAP expression and suppressed autophagy in breast cancer cells. XIAP was confirmed as a direct target of $m i R-23 a$ by reporter assay utilizing the 3'UTR of XIAP. In vitro, forced expression of $m i R-23 a$ promoted autophagy, colony formation, migration and invasion of breast cancer cell by down-regulation of XIAP expression. However, miR-23a inhibited apoptosis of breast cancer cells independent of XIAP. Xenograft models confirmed the effect of miR-23a on expression of XIAP and LC3 and that miR-23a promoted breast cancer cell invasiveness. Therefore, our study demonstrates that miR-23a modulates XIAP-mediated autophagy and promotes survival and migration in breast cancer cells and hence provides important new insights into the understanding of the development and progression of breast cancer.

\section{INTRODUCTION}

Autophagy is a cell self-degradation process for long-lived proteins and damaged organelles. Autophagy is present in cells at a low basal level and can be promoted by diverse stressful conditions, such as adaptation to starvation, oxidative or genotoxic stress, and elimination of pathogens $[1,2]$. The role of autophagy in cancer 
development and progression remains ambiguous. Different studies have demonstrated that autophagic process may function in both a tumor suppressor and oncogenic role [3, 4]. In vivo depletion of the expression of autophagy-related genes, such as BECN1 and ATG5, has been reported to lead to tumor cell survival [5-8]. In contrast, autophagy may enhance tumor cell survival, especially in oncogenic $R A S$-driven cancer [9-11]. Hence, a better molecular understanding of the autophagic process will assist in delineating its roles in cancer progression.

$X$-linked inhibitor of apoptosis $(X I A P)$, is a member of the "inhibitors of apoptosis" (IAP) family and characterized by the presence of at least one baculovirus IAP repeat (BIR) structural domain [12]. $X I A P$ possesses the most potent anti-apoptotic capacity by binding and inhibiting of caspases (caspase-3, 7, and 9) in vitro $[13,14]$. XIAP protein levels are regulated both transcriptionally and post-transcriptionally [15-18]. Our recent study demonstrated that XIAP was able to suppress autophagic activity of diverse tumor cell types by the Mdm2-p53 pathway independent of its anti-apoptosis function $[19,20]$. However, the mechanism involved in the regulation of $X I A P$ in autophagy is unknown.

Recent studies have identified microRNAs (miRNAs) as novel regulators of autophagy [21-23]. miRNAs are short $(19 \sim 25$ nucleotides $)$ non-coding RNAs, which may act as negative regulators of gene expression by binding to a target mRNA, resulting in posttranscriptional or translational repression [24, 25]. To date, only a few of miRNAs have been reported to modulate autophagic activity directly. MiR-30d was observed to impair the autophagic process by targeting multiple genes in the autophagic pathway [26]. $\mathrm{miR}-376 \mathrm{a}$ regulates starvation-induced autophagy by controlling of $A T G 4 C$ and $B E C N 1$ transcript and protein levels [27]. MiR-199a-5p plays differential roles in radiationinduced autophagy in breast cancer cells by regulating the expression level of $D R A M 1$ and BECN1 [28]. Herein, to investigate the regulatory mechanism of XIAP in cell autophagy, we scanned several miRNAs and identified $m i R-23 a$ as a target miRNA for $X I A P$-mediated autophagy and also play a role in cell viability, invasion and migration of breast cancer.

\section{RESULTS}

\section{Autophagy are associated with $X I A P$}

To trigger autophagy, MCF-7 cells were cultured with or without Earle's balanced salt solution (EBSS) in a time-dependent manner. As reported in our previous study, $X I A P$ inhibited autophagy via XIAP-Mdm2-p53 signaling pathway [19]. QRT-PCR was performed to ensure the expression of XIAP and autophagy related genes including ATG5, ATG7, ATG12 and Beclin1. As shown in Figure 1A, the expression levels of the autophagy related genes were all increased, which suggested that EBSS induced autophagy in these cells. Meanwhile, the expression level of XIAP mRNA was also increased (Figure 1B). To verify these results, we further analyzed the protein levels of $X I A P$ and determined the conversion of LC3-I (cytosolic form) to $L C 3-I I$ (membrane-bound lipidated form) by Western blot analysis. To our surprise, the protein level of XIAP was decreased, and LC3-II/LC3-I conversion ratio was increased, in the presence of EBSS (Figure 1C). The gray value we calculated as shown in Figure 1D. We also used 3-MA, an autophagy inhibitor, in the EBSSexposed cells, and the expression level of SQSTM1/ $P 62$ protein was increased and $L C 3-I I / L C 3-I$ conversion ratio was decreased. This result clarified the observed increase in LC3-II is suggestive of induction of autophagy (Supplementary Figure 1). Hence, there exists discordance between $X I A P$ mRNA and protein levels in the process of autophagy, suggesting that XIAP may be regulated at a post-transcriptional level, potentially by miRNAs. To determine whether miRNAs potentially participated in regulating autophagy, we identified several miRNAs potentially targeting XIAP by bioinformatic analysis, including $m i R-24, m i R-7, m i R-23 a$ and $m i R-513 a-5 p$. Of these miRNAs, $m i R-23 a$ not only significantly downregulated the expression of $X I A P$, but also increased $L C 3$ $I I / L C 3-I$ conversion ratio in both MCF-7 and T47D cells (Figure 2A). We therefore selected $m i R-23 a$ to further investigate the influence of miRNAs on XIAP-mediated autophagy.

\section{Overexpression of $m i R-23 a$ enhanced autophagy}

To explore the role of miRNAs in autophagy, we performed qRT-PCR analysis for the expression levels of $m i R-24, m i R-7, m i R-513 a-5 p$ and $m i R-23 a$ in MCF-7 and T47D cells treated with EBSS. The level of $m i R-23 a$ expression was the most increased of 4 miRNAs in cells cultured with EBSS, compared with cells cultured with normal medium (Figure 2B). By determination of XIAP expression in common mammary epithelial and breast cancer cell lines, we selected T47D and MCF-7, as a couple of model cell lines with relatively high and low expression of XIAP respectively (Figure 2C). We performed Western blot analysis to detect LC3-II/LC3-I conversion ratio in T47D and MCF-7 cells after transfection with $m i R-23 a$ mimics and $m i R$ $23 a$ ASO, respectively. MiR-23a mimics diminished the expression of SQSTM1/P62 protein and increased LC3$I I / L C 3-I$ conversion ratio in T47D cells. In contrast, $m i R-23 a$ ASO significantly increased the expression of SQSTM1/P62 protein and decreased LC3-II / LC3-I conversion ratio in MCF-7 cells (Figure 2D). However, there is not a significant change about the expression of SQSTM1/P62 and XIAP protein after transfection with miR-23a mimics or ASO in non-tumorigenic MCF-10A (Figure 2E). Next, miR-23a mimics and miR-23a ASO, 
respectively, were transfected into T47D and MCF-7 cells together with the GFP-LC3 plasmid and examined by fluorescence microscopy. As shown in Figure 2F, there was a significant increase of GFP- $L C 3$ puncta in miR-23a mimics transfected cells and a decrease of GFP$L C 3$ puncta in miR-23a ASO transfected cells both in nonstarved and EBSS-exposed breast cancer cells. Consistent with the GFP-LC3 puncta formation assay, we observed that accumulation of autophagosomes was increased in $m i R-23 a$ mimics transfected cells by transmission electron microscopy (Figure 2G).

\section{MiR-23a directly targeted XIAP $3^{\prime} U T R$}

Having established the function of $m i R-23 a$ in autophagy, we next determined whether $m i R-23 a$ directly targeted XIAP. Firstly, we identified two potential binding sites of $m i R-23 a$ in the XIAP-3'UTR by Targetscan [29] (Figure $3 \mathrm{~A}$ ). We then performed qRT-PCR to examine the level of XIAP mRNA in cells transfected with miR-23a mimics and miR-23a ASO. As shown in Supplementary Figure 2, $m i R-23 a$ produced a slight decrease in the XIAP mRNA level and $m i R-23 a$ ASO exerted the opposite

A

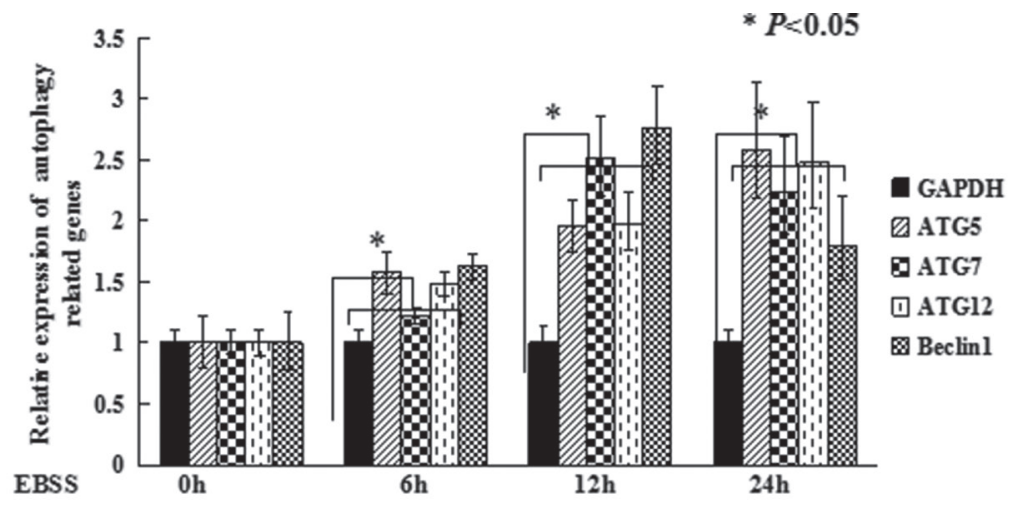

B

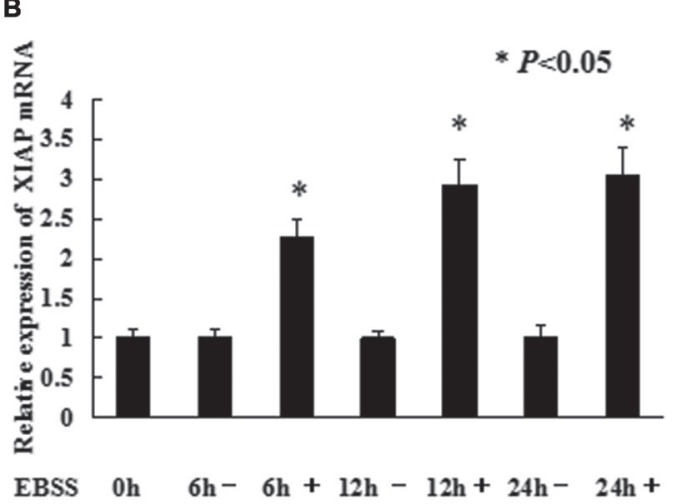

C

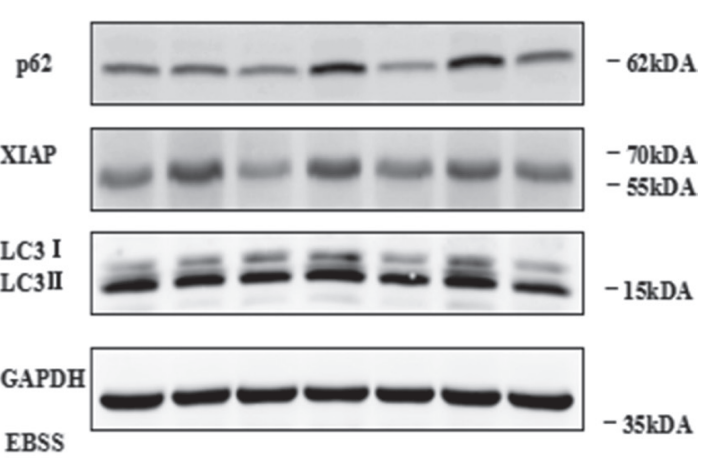

$0 h \quad 6 h-6 h+12 h-12 h+24 h-24 h+$

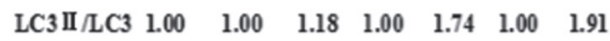

D

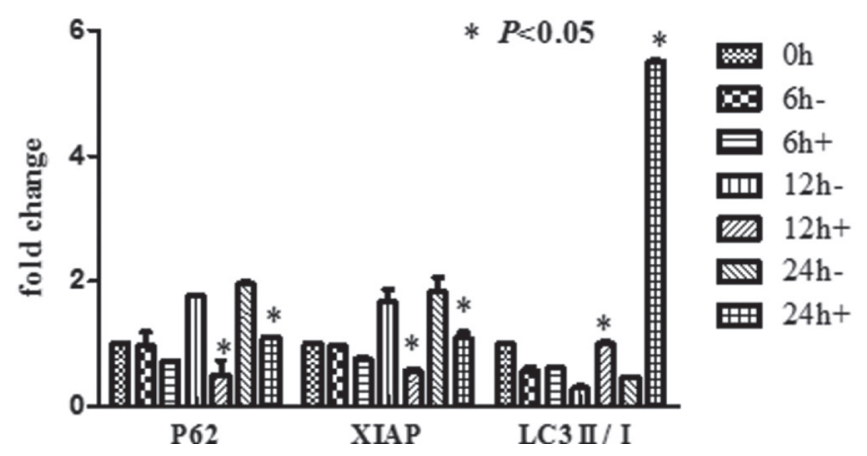

Figure 1: EBSS induces autophagy in breast cancer cells. (A and B) MCF-7 cells at 80\%-90\% confluence were cultured with EBSS for $0,6,12$, and $24 \mathrm{~h}$, compared with normal medium. Cells were collected for qRT-PCR to quantify the expression level of the autophagy related genes and XIAP. The error bars indicate the standard error of the mean (S.E.M) for three independent experiments $(*, P<0.05)$. (C) Western blot analysis of XIAP and LC3-II/I expression after MCF-7 cells treated with EBSS. (D) The gray value of P62, $X I A P$ and $L C 3-I I / I$ was calculated. 


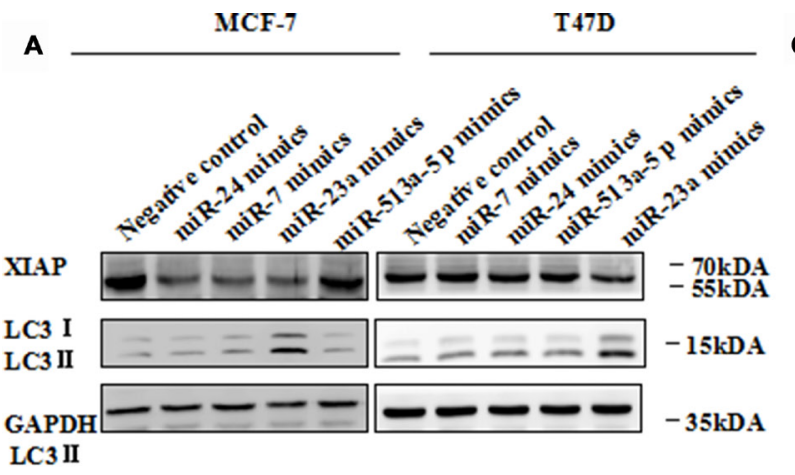

c

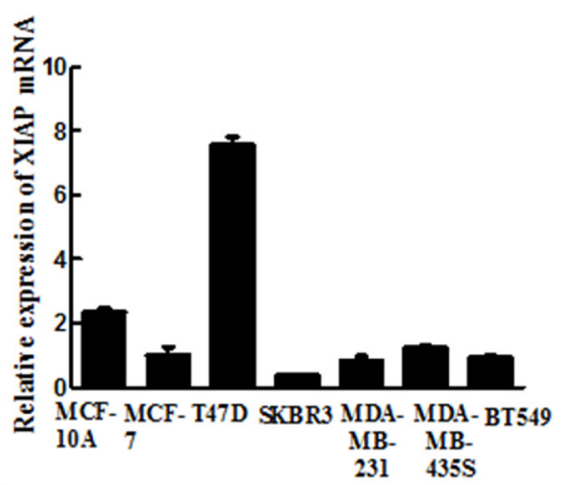

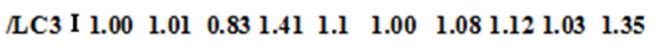
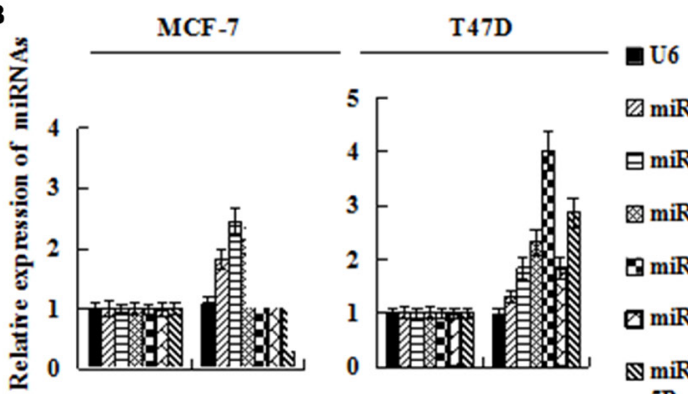

D

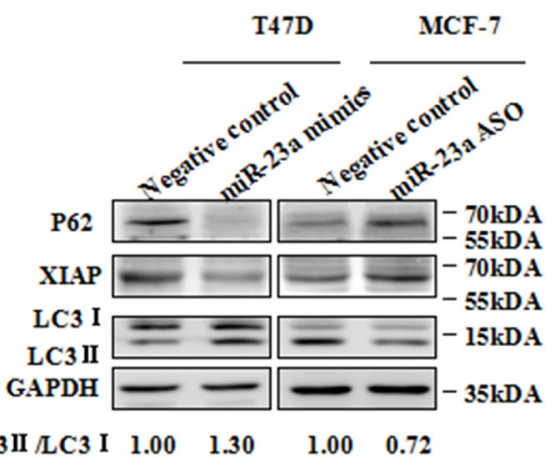

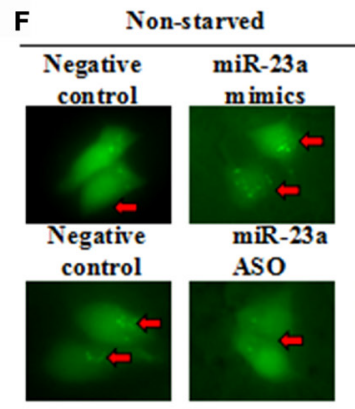

EBSS-exposed

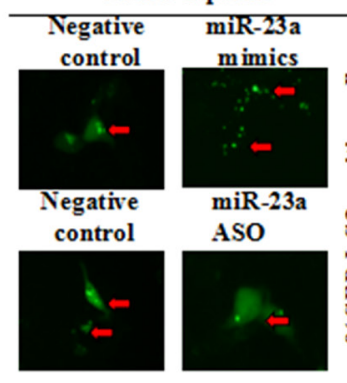

ĐiR7

घmiR24

圆 miR24-2

GiR-23a

U miR-27a

$\mathbb{S}$ miR-513a-

$5 P$

$\begin{array}{lllll}\text { LC3 II / LC3 I } & 1.00 & 1.30 & 1.00 & 0.72\end{array}$

E

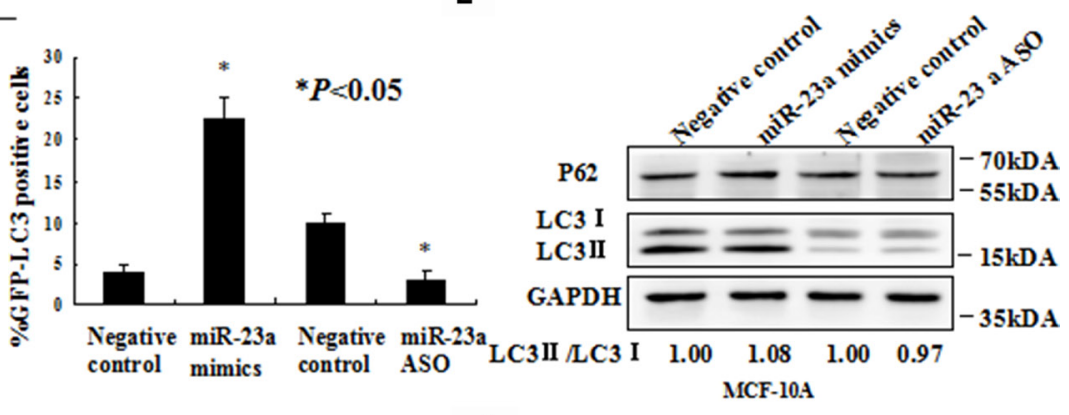

G

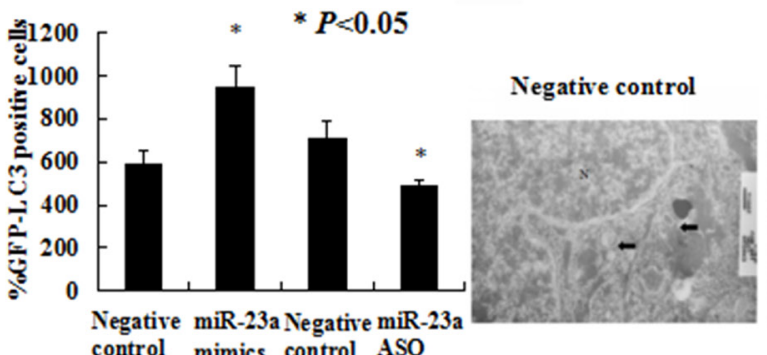

miR-23a mimics

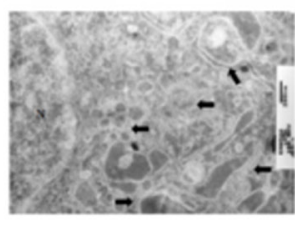

Figure 2: Forced expression of $\boldsymbol{m i R}-23 \boldsymbol{a}$ induces autophagic activity. (A) MCF-7 and T47D cells were transfected with $m i R-24$ mimics, $m i R-7$ mimics, $m i R-23 a$ mimics and $m i R-513 a-5 p$ mimics. Forty-eight hours later, $L C 3-I I / I$ proteins were detected by Western blot. (B) EBSS induced miR-23a expression strongly in MCF-7 and T47D cells. Cells were treated with EBSS and compared cells grown in with normal medium. Shown is the qRT-PCR analysis for $m i R-24, m i R-7, m i R-513 a-5 p$ and $m i R-23 a$. U6 snRNA was used as an input control $(*, P<0.05)$. (C) XIAP mRNA expression in seven human mammary cell lines was analyzed by qRT-PCR. (D) Expression of $m i R-23 a$ induces $L C 3$ conversion and SQSTM1/P62 degradation. T47D cells were transiently transfected with $m i R-23 a$ mimics and MCF-7 cells were transiently transfected with $m i R-23 a$ ASO. Total cellular protein was isolated and subjected to Western blot analysis. GAPDH was used as input control. (E) Expression of miR-23a did not significantly induce $L C 3$ conversion and SQSTM1/P62 degradation. MCF-10A cells were transiently transfected with $m i R-23 a$ mimics and $m i R-23 a$ ASO. Total cellular protein was isolated and subjected to Western blot analysis. $G A P D H$ was used as input control. (F) GFP- $L C 3$ puncta formation was analyzed by fluorescence microscopy (200× magnification). Black arrows indicate clusters of GFP- $L C 3$ puncta in cells. Quantification of GFP- $L C 3$ puncta in E (mean \pm S.D of independent experiments, $n=3,{ }^{*} P<0.05$ ). (G) Autophagy was evaluated in breast cancer cells by electron microscopy. Scale bars, $200 \mathrm{~nm}$. 
effect. Western blot analysis showed that the cellular levels of XIAP protein were significantly decreased in $m i R-23 a$ mimics transfected cells and significantly increased in miR-23a ASO transfected cells (Figure 2D).

Luciferase reporter assay demonstrated that $m i R-23 a$ directly interacted with XIAP $3^{\prime} U T R$ and this interaction occurred at positions 3115-3121 (Figure 3B), but not positions 1017-1024 (data not shown). We next determined whether promotion of autophagy by $m i R-23 a$ was mediated by XIAP. We first constructed a XIAP expression vector, pIRESneo3/XIAP, and the forced expression of $X I A P$ was confirmed by qRT-PCR (Supplementary Figure 3) and Western blot analysis (Figure 3C). We also used Embelin, an inhibitor of XIAP, to verify the function of $X I A P$ on autophagy, by western blot analysis for LC3-II/LC3-I (Figure 3D). We observed that Embelin promoted autophagy in a dose-dependent manner $(0-120 \mathrm{ug} / \mathrm{ml})$. By transfection of $m i R-23 a$ mimics, $m i R-23 a$ mimics plus XIAP expression plasmid or controls, we observed that forced expression of XIAP significantly abrogated $m i R$-23a-induced autophagy in T47D cells (Figure 3E).

For the essential role of XIAP in regulating cell apoptosis, we may ask that whether $m i R-23 a$-induced autophagy was associated with apoptosis. To this end, we transfected T47D cells with miR-23a mimics or a negative control followed by treatment with either caspase inhibitor Z-VAD-FMK or vehicle (DMSO). It was observed that the effect of $m i R-23 a$ on $L C 3-I I / L C 3-I$ conversion ratio and the protein level of XIAP in T47D cells was not affected by Z-VAD-FMK treatment (Figure $3 \mathrm{~F}$ ), suggesting that $m i R-23 a$ induced XIAP-mediated autophagy was independent of caspase-mediated apoptosis.

\section{Effects of $m i R-23 a$ on breast cancer cell viability, migration, invasion and apoptosis}

We next explored the effect of $m i R-23 a$ on the behaviors of breast cancer cells in vitro. We observed that knockdown of $m i R-23 a$ expression in MCF-7 cells by $m i R-23 a$ ASO did not significantly alter cell viability $(P>0.05)$, and forced-expression of $m i R-23 a$ in T47D cells by $m i R-23 a$ mimics did not significantly reduce cell viability $(P>0.05)$ in MTT assay (data not shown). However, in a long-term cell survival assay, up-regulation of $m i R-23 a$ expression by transfecting T47D cells with the specific mimics significantly increased cell colony formation, and downregulation of $m i R-23 a$ expression by transfecting MCF-7 cells with the specific ASO significantly decreased cell colony formation (Figure 4A).

We next used transwell assays to assess the impact of $m i R-23 a$ on cell migration and invasion. As shown in Supplementary Figure 4, T47D cells transfected with miR$23 a$ mimics exhibited increased migration and invasion compared with controls. Moreover, co-transfection of cells with $m i R-23 a$ mimics and the XIAP expression plasmid demonstrated that expression of XIAP significantly abrogated $m i R-23 a$ mimic-promoted tumor cell migration and invasion (Supplementary Figure 4A). Furthermore, $48 \mathrm{~h}$ after transient transfection of $m i R-23 \mathrm{a}$ mimics, cells were treated with the autophagy inhibitor 3-MA for $24 \mathrm{~h}$. 3-MA significantly abrogated $m i R-23 a$ mimic-promoted tumor cell migration and invasion (Supplementary Figure 4B). Consistently, MCF-7 cells transfected with $m i R-23 a$ ASO exhibited decreased migration and invasion, compared with the control. Moreover, XIAP inhibitor Embelin and autophagy inducer EBSS dramatically abrogated $m i R-23 a$ ASO-decreased tumor cell migration and invasion (Supplementary Figure 4C, 4D). These data implied that $m i R-23 a$ promoted autophagy and cell migration and invasion using similar signaling pathways by regulation of $X I A P$.

Previous studies have demonstrated that $m i R-23 a$ suppressed apoptosis in colorectal and gastric cancer cells [30, 31]. Consistently, we observed that $m i R-23 a$ significantly inhibited apoptosis of breast cancer cells (Figure 4B). Next, we determined whether XIAP was involved in $m i R$-23a-regulated apoptosis. To this end, we transfected $m i R-23 a$ mimics, $m i R-23 a$ mimics plus XIAP expression plasmid or controls into T47D cells and observed that forced-expression of XIAP did not abrogate the antiapoptotic effect of $m i R-23 a$ in these cells (Figure 4C).

\section{Effects of $m i R-23 a$ on $X I A P$ expression and tumor cell invasiveness in nude mouse xenografts}

To determine the effect of $m i R-23 a$ expression in breast cancer cells in vivo, we injected MCF-7-VEC and MCF-7-miR-23a cells orthotopically into the mammary fat pad of female BALB/c nude mice, respectively. Histology of xenografts showed that tumors derived from MCF7-miR-23a cells were poorly encapsulated and highly invasive in comparison to tumors derived from control cells (Figure 5). More aggressive behavior was observed in the margin of tumor nodule of MCF-7-miR-23a cells (red arrow) compared to that of MCF-7-VEC cells (blue arrow). By use of immunohistochemistry, we also confirmed decreased protein expression of XIAP, P62 and increased $L C 3$ expression in tumors generated by MCF7-miR-23a cells compared to those generated by control cells (Figure 5).

\section{DISCUSSION}

We have previously demonstrated that XIAP suppressed diverse cell autophagy independent of its regulation of apoptosis [19]. However, the upstream regulation of $X I A P$-mediated autophagy is unknown. We observed discordant expression of XIAP mRNA and protein after induction of autophagy which implied that XIAP may be post-transcriptionally regulated. We first identified $m i R-23 a$ as a regulator of autophagy and 
A Position 3115-3121 of XIAP 3' UTR

hsa-miR-23a

Position 1017-1024 of XIAP 3' UTR

hsa-miR-23a

B

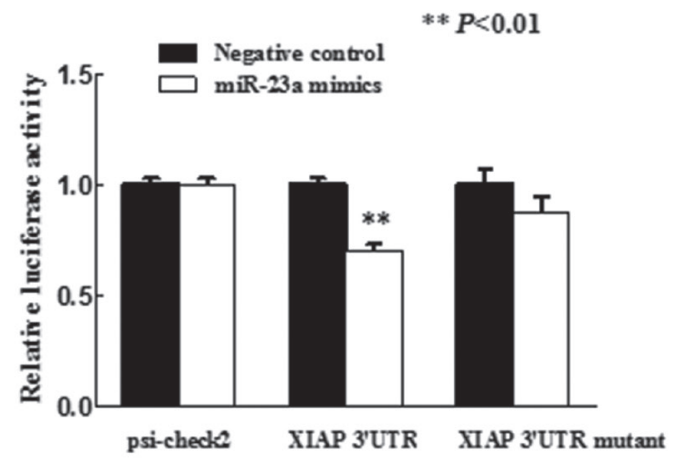

C

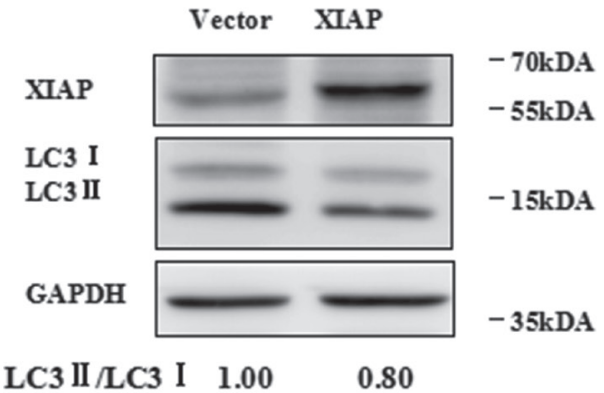

E

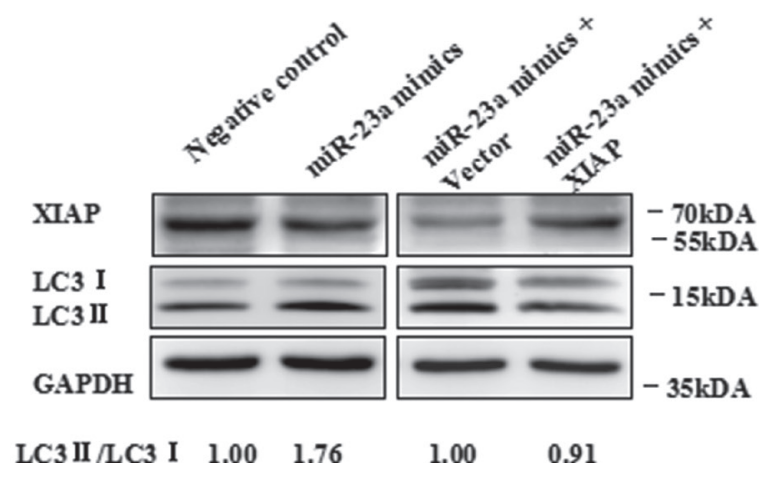

\section{5'...GUAGUGAGUGUAUAUAAUGUGAU}

| | || || |

3'CCUUUAGGGACCGUUACACUA

\section{5' ...AACCUUUUUGGUGCCAAUGUGAA.. | | || || | \\ 3' CCUUUAGgGaCcGuUacacua}

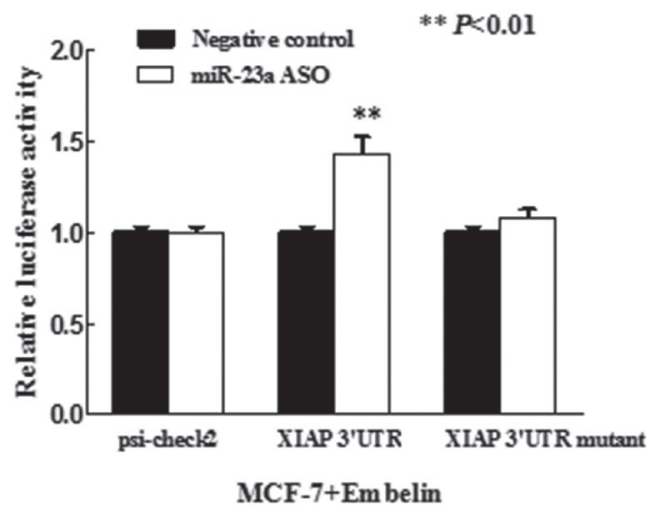

D

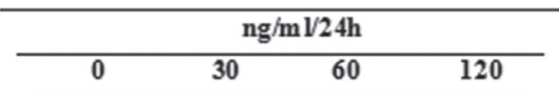

XIAP
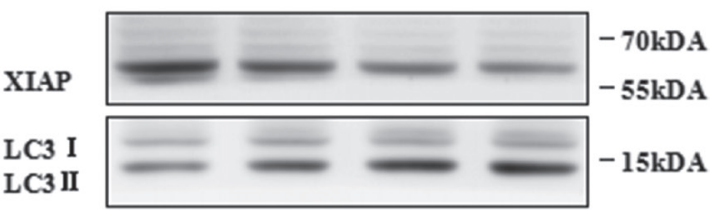

LC3 II

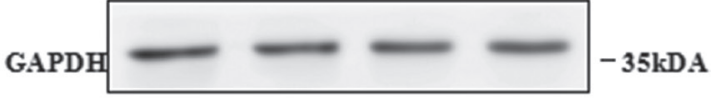

$\mathrm{LC3}$ II $/ \mathrm{LC} 3 \mathrm{I} \quad 1.00 \quad 1.44 \quad 1.83 \quad 2.12$

$\mathbf{F}$

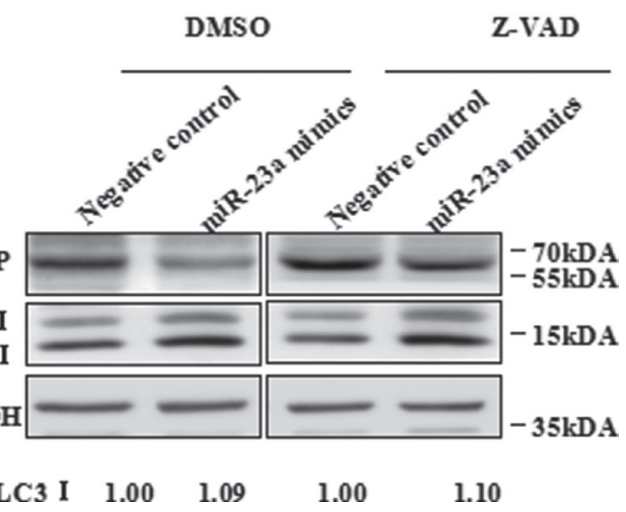

Figure 3: MiR-23a directly targets XIAP 3'UTR. (A) Predicted binding sequences between miR-23a and seed matches in XIAP$3^{\prime} U T R$. (B) Luciferase reporter analysis of XIAP $3^{\prime} U T R$ were performed after co-transfection with miR-23a in T47D cells and after co-transfection with miR-23a ASO in MCF-7 cells. The error bars indicate the standard error of the mean (S.E.M.) for three independent experiments $(* P<0.05)$. (C) Expression of XIAP inhibits autophagy. Western blot analysis is shown. Vector is used as an internal control. (D) MCF-7 cells were treated with Embelin as indicated and XIAP protein level and LC3-II/I expression were determined by Western blot analysis with anti-XIAP and anti- $L C 3$, respectively. (E) Western blot. T47D cells were grown and transfected with miR-23a mimics, $m i R-23 a$ mimics plus vector, $m i R-23 a$ mimics plus expression of $X I A P$, or negative control. Then, total cellular proteins from these cells were subjected to Western blot analysis of XIAP, LC3 expression. (F) Western blot. Forty-eight hours after transfected with miR-23a mimics and Negative control in T47D cells, which were treated with $20 \mathrm{uM}$ Z-VAD-FMK or DMSO for $2 \mathrm{~h}$. Cell lysates were analyzed by Western blotting. 
demonstrated that $X I A P$ is a target gene of $m i R-23 a$. Finally, we demonstrated that $m i R-23 a$ enhanced breast cancer cell autophagic activity through modulation of $X I A P$ expression and also promoted cell migration and invasion.

The function of autophagy in cancer development and/or progression is considered to be cell contextdependent [4, 32]. Autophagy ensures the delivery of metabolic substrates to cells so as to fulfill their energy demand during stress, thus supporting cell survival $[33,34]$. However, hyperactivation of autophagy will result in cell death designated as 'autophagic cell death'. Amino acid deprivation promotes autophagy in different organs and in cultured cells $[35,36]$. Consistent with these reports, we have demonstrated that amino acid deficient increased autophagy activity in breast cancer cells.
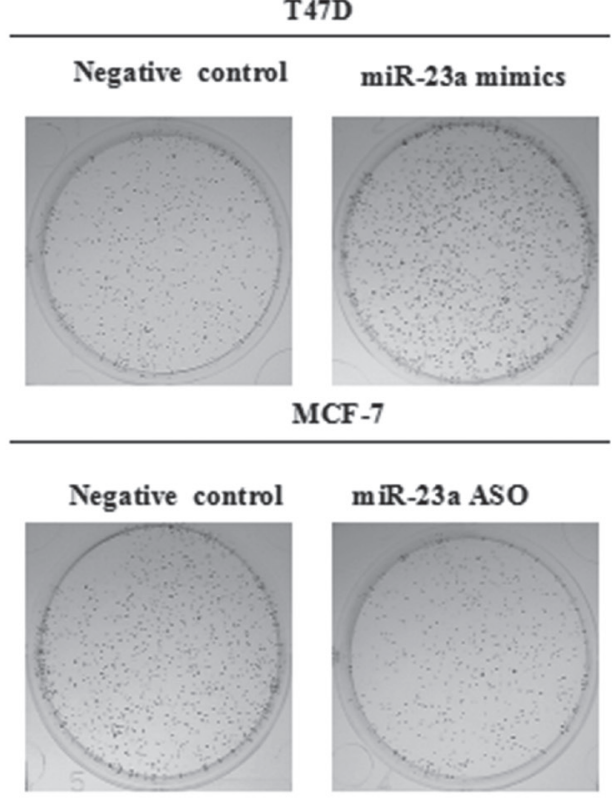

B
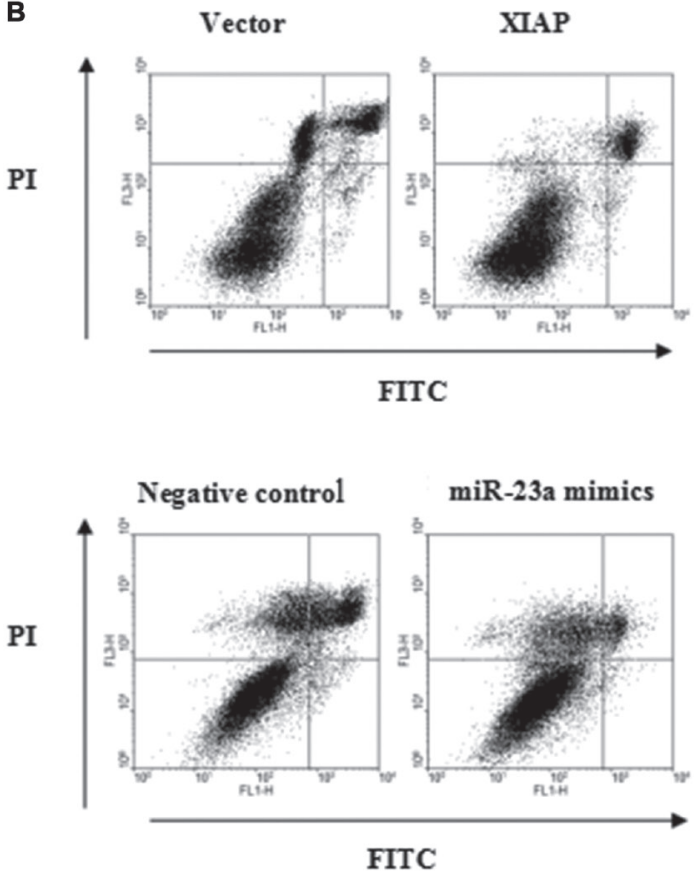

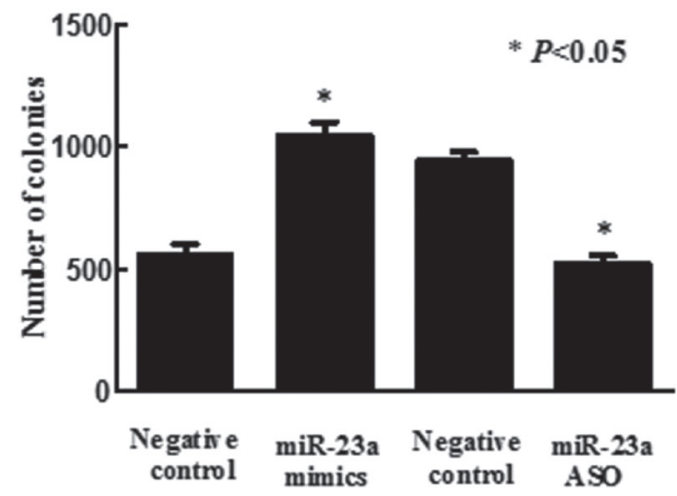

C

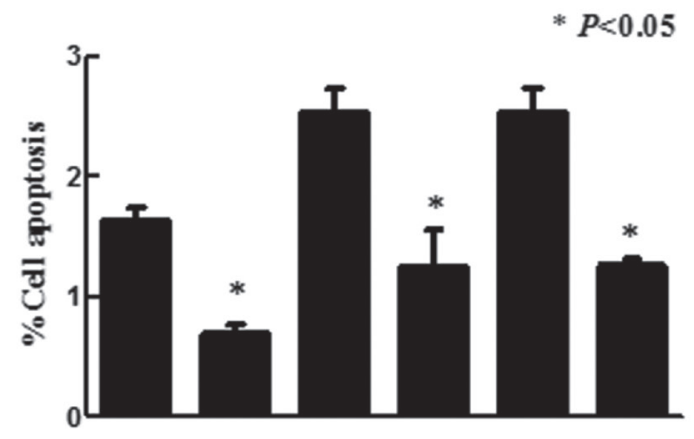

Ne gativ e miR-23aVector XIAP Ne gativ e miR-23a control mimics control mimicst Vector XIAP

Figure 4: Effects of $\boldsymbol{m i R}-23 \boldsymbol{a}$ on breast cancer cell viability and apoptosis. (A) Colony formation assays. T47D and MCF-7 cells were grown and transiently transfected with $m i R-23 a$ mimics and $m i R-23 a \mathrm{ASO}$, respectively, and then seeded in $0.35 \%$ top agarose and $10 \%$ FBS in six-well plates in triplicate. The number of colonies was counted after 10 days incubation. (B) Flow cytometric analysis of apoptosis in T47D cells after genes transfection, as evidenced by PI/Annexin V double staining and FACS analysis. (C) The apoptosis rate was quantified by a flow cytometer. Data are presented as mean $\pm \operatorname{SEM}(n=3, * P<0.05)$. 
MCF-7 Vec
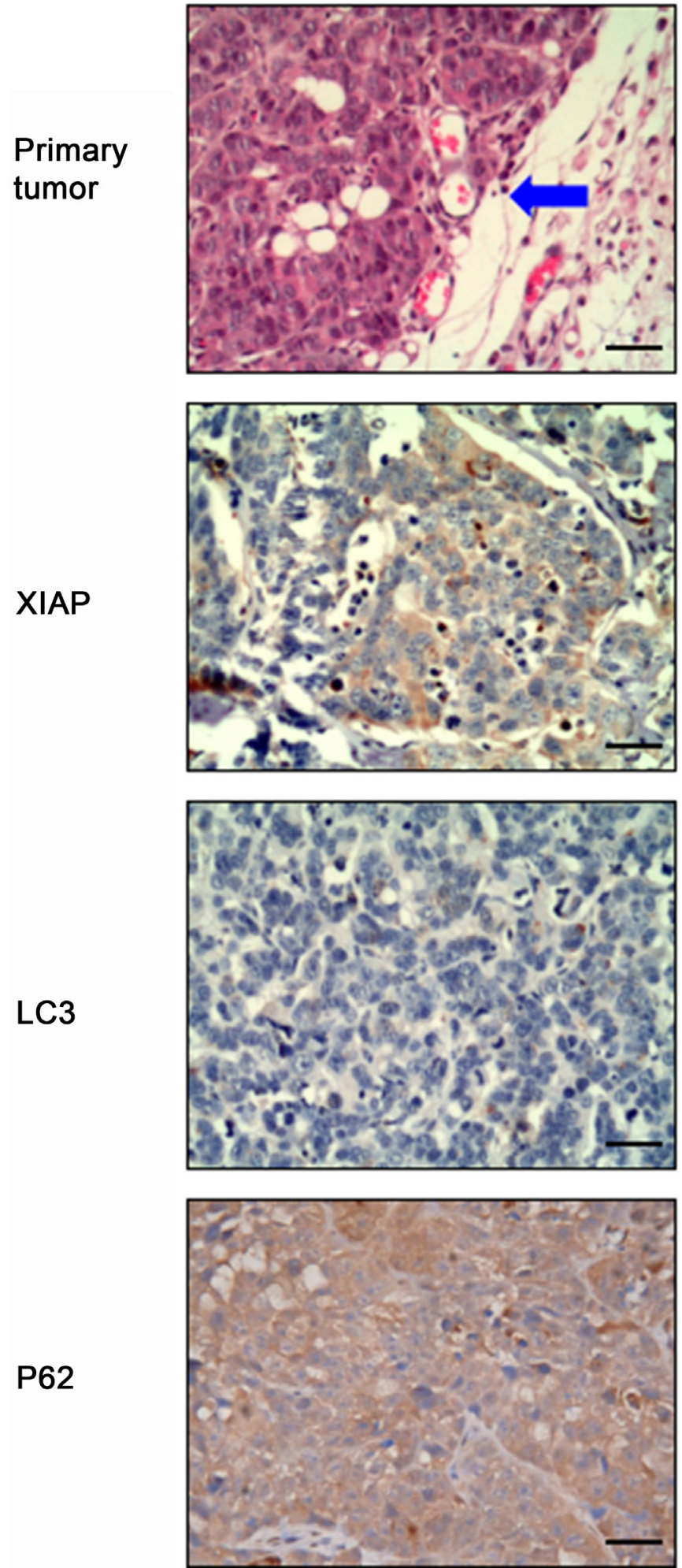

MCF-7 miR-23a
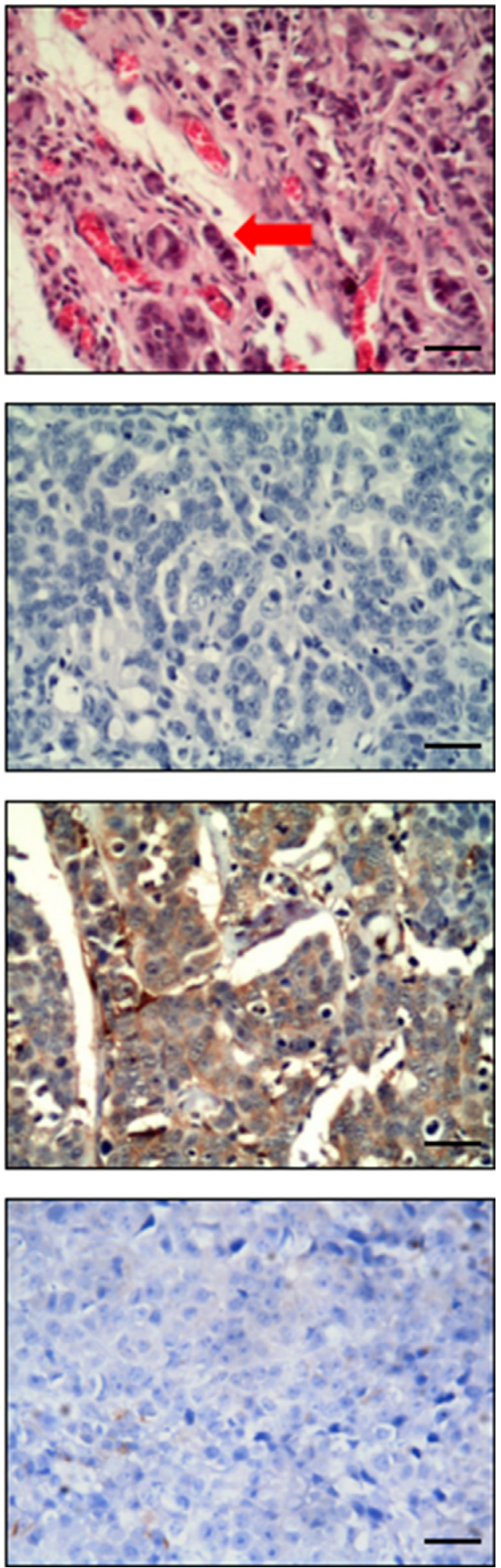

Figure 5: Effects of forced expression miR-23a on regulation of MCF-7 xenograft in nude mice. MCF-7-Negative control and MCF-7- miR-23a cells were transplanted into the mammary fat pad of female BALB/c-nu, respectively. Hematoxylin and eosin staining of tumor xenograft sections. Invasive behavior was observed at the margin of the tumors generated by MCF-7-miR-23a mimics (red arrow) compared to that of MCF-7-Negative control cells (blue arrow). (Magnification: $\times 200$ ). Representative imagines of XIAP, LC3 and P62 expression analyzed by immunohistochemistry (Magnification: $\times 200$ ). 
It has been reported that the process of autophagy is modulated by miRNAs that regulate gene expression post-transcriptionally [21-23]. In the present study, we have identified $m i R-23 a$ as a novel miRNA regulating basal autophagy. MiR-23a expression has been reported in a wide range of malignancies, including gastric, colorectal, and breast cancers [30, 31, 37]. Several lines of evidence suggest that $m i R-23 a$ functions as an oncogene and is involved in tumor development. Herein, we demonstrated that forced expression of $m i R-23 a$ inhibits apoptosis, promotes autophagy and enhances cell colony formation, migration and invasion. It was interesting to note that expression of endogenous miR$23 a$ was increased in response to cellular stress caused by amino acid depletion. Transcriptional and/or posttranscriptional regulatory mechanisms may be responsible for increased $m i R-23 a$ expression. In MCF-7 and T47D cell lines, we found that forced expression of $m i R-23 a$ resulted in a significant increase LC3-II accumulation and SQSTM1/P62 degradation. In addition, suppression of $m i R-23 a$ by specific antagonism exerted the opposite effect. While there was no significant change concerning $P 62$ and $L C 3-I I / I$ expression after transfection of $m i R-23 a$ mimics or ASO in MCF-10A cell line. Our results support the idea that there were differences between $m i R-23 a$ regulated cell lines. We further observed by transmission electron microscopy that accumulation of autophagosomes was increased in cells transfected with $m i R-23 a$ and concordantly observed enhancement of GFP-LC3 puncta formation by fluorescence microscopy.

One miRNA may modulate the expression of different target genes. By using bioinformatic analyses to search for potential target genes of $m i R-23 a$, we observed that $m i R-23 a$ may directly target XIAP mRNA. Experimentally by use of reporter assays we observed that $X I A P$ was indeed a target gene of $m i R-23 a$ as expected. The mechanisms of $m i R-23 a$-promoted cell autophagy, survival, migration and invasion required further delineation. We demonstrated that increased XIAP expression significantly abrogated miR-23a mimics-promoted breast cancer cell autophagy, migration and invasion. Furthermore, 3-MA decreased $m i R-23 a$ mimics-induced cell migration and invasion. However, the two processes of autophagy and cell migration/invasion may simply utilize similar signaling pathways and not be functionally or causally related 3-MA inhibits autophagy by acting as an inhibitor of type III PI3K [38, 39]. Enhanced $P I 3 K$ activity has also been demonstrated to promote human fibrosarcoma cell migration and invasion [40]. Additionally, XIAP is the most potent caspase inhibitor of all IAP family members and has been observed to be increased in expression in a variety of human malignancies [41-45]. Hence we determined whether a potential functional interrelationship existed between $X I A P$-mediated autophagy and XIAP mediated cell survival. We demonstrated that $m i R-23 a$ promoted $X I A P$-mediated autophagy was independent of the caspase- mediated apoptotic pathway. Interestingly, our data also revealed that $m i R-23 a$ did indeed inhibit cell apoptosis but this function was not mediated by XIAP. The results are not surprising as one miRNA may modulate the expression of different target genes with a differential functional outcome dependent on the particular cellular context. For example, Xie et al. [16] showed that miR-24 overexpression can overcome apoptosis-resistance in cancer cells via downregulation of XIAP expression. Liu et al. [30] demonstrated that $m i R-23 a$ suppressed apoptosis of gastric cancer cells by targeting the PPP2R5E gene. Herein, suppression of breast cancer cell apoptosis by $m i R-23 a$ is probably mediated by some other genes rather than XIAP.

Interestingly, the basal levels of $X I A P$ in $\mathrm{MCF}$ 7 and T47D cells were discrepant, and the mRNA level of XIAP in T47D was nearly 8 times of that in MCF-7 (Figure 2C). As reported previously, many proteins involved in stimulation of cell growth, cell survival and cancer development were expressed more strongly in T47D than in MCF7 including for example, cyclin-D3 and prohibitin $[46,47]$. Herein we consistently observed that the anti-apoptosis and anti-autophagic gene XIAP was also dramatically higher in T47D compared with MCF-7.

A compensatory mechanism that leads to increased expression of other IAP family members when XIAP expression is lost during apoptosis has been observed [48]. This work shed light on the independent relationship between autophagy and apoptosis mediated by $m i R-23 a$. It is reported that $m i R-21, m i R-155$, and $m i R-221 / 222$ may also mediate apoptotic and autophagic pathways of glioma cells, cervical cancer cells and breast cancer cells, respectively [49-52]. Similarly, we demonstrated that $m i R-23 a$ promotes autophagy and inhibits apoptosis by different mechanisms in breast cancer cells.

\section{MATERIALS AND METHODS}

\section{Cell culture and treatment}

Human breast cancer cell lines MCF-7, T47D, SKBR3, BT549, MDA-MB-231, MDA-MB-435S and a human breast non-tumorigenic cell line MCF-10A were obtained from the American Type Culture Collection (ATCC, Manassas, VA, USA). All cells were maintained in a humidified incubator at $37^{\circ} \mathrm{C}$ and $5 \% \mathrm{CO}_{2}$. Cells were treated with Earle's balanced salt solution (EBSS, Sigma) to activate starvation-induced autophagy [27]. Apoptosis inhibitor Z-VAD-FMK (Santa Cruz), autophagy inhibitor 3-MA (Sigma) and XIAP inhibitor Embelin (Santa Cruz) were treated when necessary.

\section{MiRNA transfection}

Breast cancer T47D and MCF-7 cells $\left(1.0 \times 10^{5} /\right.$ well $)$ were seeded in 6-well plates overnight and then respectively transfected with miR-23a mimics (GenePharma, Shanghai) 
or its negative control and 2'-O methylated single-stranded $m i R-23 a$ antisense oligonucleotide (ASO, GenePharma) or its negative control, and RNA duplex control using Lipofectamine 3000 (Invitrogen, Carlsbad, CA, USA) following the instructions of the manufacturer. The sequences of miRNA oligonucleotides were summarized in Supplementary Table 1.

\section{RNA extraction and quantitative real-time PCR (qRT-PCR)}

Total cellular RNA and miRNA were isolated using Trizol reagent (Invitrogen) and the mirVana miRNA Isolation Kit (Ambion, Austin, TX), respectively, according to the manufacturer's introductions. QRT-PCR were performed to detect the expression of XIAP, ATG5, ATG7, ATG12, Beclin 1, miR-23a, GAPDH, and U6 as described previously [53-55]. The sequence of the primers used for qRT-PCR was summarized in Supplementary Table 2.

\section{Western blotting analysis}

Total cellular protein and Western blotting analysis were performed according to pervious study [53, 54].The antibodies used were as follows: anti-XIAP (E-2, Santa Cruz), anti-LC3 (L7543, Sigma), anti-SQSTM1/P62 (D-3, Santa Cruz), anti-GAPDH (A-3, Santa Cruz).

\section{Immunohistochemistry assay}

For analysis of XIAP expression and $L C 3$ expression in tumors from nude mouse, a mouse anti-XIAP polyclonal antibody (H-202, Santa Cruz, 1:15) and a rabbit anti-LC3 polyclonal antibody (L7543, Sigma, 1:100) were used according to our previous study [53-55].

\section{FACS analysis}

Cell apoptosis was assayed using Annexin V- Apotosis Detection kit (BestBio, Shanghai, China) according to the manufacturer's introductions. All the experiments were performed using a FACScalibur cytometer (BD Biosciences, San Jose, CA). Each experiment was performed in triplicate and repeated at least once.

\section{GFP-LC3 Localization assay}

In order to generate expression of GFP- $L C 3$ in MCF-7 cells, we transiently expressed $m i R-23 a$ and $m i R$ $23 a$ ASO with the autophagy marker GFP-LC3, compared with negative control, $48 \mathrm{~h}$ after co-transfection, GFP-LC3 puncta were visualized under a fluorescence microscope (Olympus XSZ-D2) equipped with CCD cameras and images were captured and analyzed for presence of more than five puncta per cell.

\section{Electron microscopy}

Cells were treated as indicated and fixed with $2.5 \%$ glutaraldehyde containing $0.1 \mathrm{~mol} / \mathrm{L}$ sodium cacodylate. Samples were fixed using 1\% osmium tetroxide, followed by dehydration with an increasing concentration gradient of ethanol and propylene oxide. Samples were then embedded, cut into 50nm sections, and stained with $3 \%$ uranyl acetate and lead citrate as previously reported [19]. Images were acquired using a JEM-1200 electron microscope (JEOL, Tokyo, Japan).

\section{Luciferase reporter assay}

Cells were plated on a $24-w e l l$ plate $24 \mathrm{~h}$ before transfection at $50 \%$ confluence and then co-transfected with 0.2 ug of psiCHECK2-XIAP 3'UTR or psiCHECK2 control vector and $30 \mathrm{nM} m i R-23 a$ mimics or its negative control by using Lipofectamine $3000.48 \mathrm{~h}$ after transfection, cells were harvested, and reporter assays were performed using a dual luciferase assay system (Promega). Each transfection was performed in triplicate. The primers for XIAP 3'UTR were 5'-GCGCGCACTCGA GTCTAACTCTATAGTAGGCATGTTATG-3' (sense) and 5'-TATATGCGGCCGCCTACAATGAATGCCAGA TTATACAGC-3' (antisense).

\section{MTT assay and colony formation assay}

Cells were cultured in 96-well plates at 5000 cells per well, $24 \mathrm{~h}$ after transfection. The 3-(4, 5-dimethylthiazol-2-yl)-2, 5-diphenyl-tetrazolium bromide (MTT) assay was used to determine cell viability $24 \mathrm{~h}$, $48 \mathrm{~h}, 72 \mathrm{~h}$, and $96 \mathrm{~h}$ after the cells were seed. Absorbance at $570 \mathrm{~nm}$ was measured using an automatic microplate reader. (Infinite M200; Tecan, Grodig, Austria). Next, the cells were cultured for 10 days, and colonies were counted. The experiment was performed in triplicate. Data are expressed as mean \pm standard deviation (SD).

\section{Cell migration and invasion assay}

To determine whether the effect of miR-23a on breast cancer cell migration and invasion was medicated by XIAP in vitro, we used a Transwell insert (8 $\mu \mathrm{m}$, Corning, NY). T47D cells were transfected with negative control, miR-23a mimics and $m i R$ $23 a$ mimics plus plasmid XIAP or an autophagy inhibitor, 3-MA. Meanwhile, negative control, miR$23 a \mathrm{ASO}$ and $m i R-23 a$ ASO plus XIAP inhibitor Embelin or EBSS were transfected in MCF-7 cells. Transwell assays were performed as described previously [53-55]. Five macroscopic areas were selected randomly and counted the cell numbers. All experiments were experiment in triplicate. 


\section{Nude mouse breast cancer cell xenograft assay}

All animal work was performed according to Institutional Animal Care and Use Committee guidelines (available at www.iacuc.org) with local institutional approval. Briefly, the 5-week-old female BALB/c nude mice (Hunan SJA Laboratory Animal Co., Ltd.) were used for studies. $5 \times 10^{6}$ MCF-7-VEC and MCF-7-miR-23a cells were suspended in $120 \mu \mathrm{l}$ Matrigel/PBS at a ratio of 1:1 $(\mathrm{v} / \mathrm{v})$ and then injected into the mammary fat pad of female BALB/c-nu. One estrogen pellet was implanted into each mouse before injection. When animals were sacrificed, primary tumors were harvested for further analysis.

\section{Bioinformatic analysis and statistical analysis}

The miRNA database TargetScan (release 5.1, http:// www.targetscan.org/) was used to predict the targeting miRNAs of XIAP. Statistical evaluation was shown as means \pm standard deviation (SD). Date was analyzed by SPSS 16.0 software. Differences between groups were compared using Student $t$ test for continuous variables. $P$ values were considered significance if $P<0.05$.

\section{Author contributions}

PC, YHH, XH, SQT, HY and WYW performed experiments and summarized the data; WYW, XNW, KSD and ZSW designed experiments; YHH, PEL and ZSW drafted the manuscript and critically discussed the data and manuscript; all authors have read and approved the final manuscript.

\section{CONFLICTS OF INTEREST}

The authors declare that there was no competing interest in this work.

\section{FUNDING}

This work was supported in part by grants from the National Nature Science Foundation of China (\#81472493, 81572305 and 81372476), the Program for Excellent Talents and the scientific research program from Anhui Medical University (2013xkj006), Anhui provincial academic and technical leader reserve candidate (\#2016H074), Key Program of Outstanding Young Talents in Higher Education Institutions of Anhui (\#gxyqZD2016046), the Program for youth scientific research star from the Second affiliated Hospital of Anhui Medical University (2014KA02).

\section{REFERENCES}

1. Rabinowitz JD, White E. Autophagy and metabolism. Science. 2010; 330:1344-8. https://doi.org/10.1126/ science.1193497.
2. Levine B, Kroemer G. Autophagy in the pathogenesis of disease. Cell. 2008; 132:27-42. https://doi.org/10.1016/j. cell.2007.12.018.

3. Bhutia SK, Mukhopadhyay S, Sinha N, Das DN, Panda PK, Patra SK, Maiti TK, Mandal M, Dent P, Wang XY, Das SK, Sarkar D, Fisher PB. Autophagy: cancer's friend or foe? Adv Cancer Res. 2013; 118:61-95. https://doi.org/10.1016/ B978-0-12-407173-5.00003-0.

4. Ogier-Denis E, Codogno P. Autophagy: a barrier or an adaptive response to cancer. Biochim Biophys Acta. 2003; 1603:113-28.

5. Liang XH, Jackson S, Seaman M, Brown K, Kempkes B, Hibshoosh H, Levine B. Induction of autophagy and inhibition of tumorigenesis by beclin 1. Nature. 1999; 402:672-6. https://doi.org/10.1038/45257.

6. Qu X, Yu J, Bhagat G, Furuya N, Hibshoosh H, Troxel A, Rosen J, Eskelinen EL, Mizushima N, Ohsumi Y, Cattoretti G, Levine B. Promotion of tumorigenesis by heterozygous disruption of the beclin 1 autophagy gene. J Clin Invest. 2003; 112:1809-20. https://doi.org/10.1172/ JCI20039.

7. Takamura A, Komatsu M, Hara T, Sakamoto A, Kishi C, Waguri S, Eishi Y, Hino O, Tanaka K, Mizushima N. Autophagy-deficient mice develop multiple liver tumors. Genes Dev. 2011; 25:795-800. https://doi.org/10.1101/gad.2016211.

8. Yue Z, Jin S, Yang C, Levine AJ, Heintz N. Beclin 1, an autophagy gene essential for early embryonic development, is a haploinsufficient tumor suppressor. Proc Natl Acad Sci USA. 2003; 100:15077-82. https://doi.org/10.1073/ pnas. 2436255100 .

9. Guo JY, Chen HY, Mathew R, Fan J, Strohecker AM, KarsliUzunbas G, Kamphorst JJ, Chen G, Lemons JM, Karantza V, Coller HA, Dipaola RS, Gelinas C, et al. Activated Ras requires autophagy to maintain oxidative metabolism and tumorigenesis. Genes Dev. 2011; 25:460-70. https://doi. org/10.1101/gad.2016311.

10. Lock R, Roy S, Kenific CM, Su JS, Salas E, Ronen SM, Debnath J. Autophagy facilitates glycolysis during Rasmediated oncogenic transformation. Mol Biol Cell. 2011; 22:165-78. https://doi.org/10.1091/mbc.E10-06-0500.

11. Yang S, Wang X, Contino G, Liesa M, Sahin E, Ying H, Bause A, Li Y, Stommel JM, Dell'antonio G, Mautner J, Tonon G, Haigis M, et al. Pancreatic cancers require autophagy for tumor growth. Genes Dev. 2011; 25:717-29. https://doi.org/10.1101/gad.2016111.

12. Miller LK. An exegesis of IAPs: salvation and surprises from BIR motifs. Trends Cell Biol. 1999; 9:323-8.

13. Deveraux QL, Takahashi R, Salvesen GS, Reed JC. $\mathrm{X}$-linked IAP is a direct inhibitor of cell-death proteases. Nature. 1997; 388:300-4. https://doi.org/10.1038/40901.

14. Eckelman BP, Salvesen GS, Scott FL. Human inhibitor of apoptosis proteins: why XIAP is the black sheep of the family. EMBO Rep. 2006; 7:988-94. https://doi. org/10.1038/sj.embor.7400795. 
15. Liu S, Zhang P, Chen Z, Liu M, Li X, Tang H. MicroRNA-7 downregulates XIAP expression to suppress cell growth and promote apoptosis in cervical cancer cells. FEBS Lett. 2013; 587:2247-53. https://doi.org/10.1016/j.febslet.2013.05.054.

16. Xie Y, Tobin LA, Camps J, Wangsa D, Yang J, Rao M, Witasp E, Awad KS, Yoo N, Ried T, Kwong KF. MicroRNA-24 regulates XIAP to reduce the apoptosis threshold in cancer cells. Oncogene. 2013; 32:2442-51. https://doi.org/10.1038/onc.2012.258.

17. Shin S, Moon KC, Park KU, Ha E. MicroRNA-513a$5 p$ mediates TNF-alpha and LPS induced apoptosis via downregulation of X-linked inhibitor of apoptotic protein in endothelial cells. Biochimie. 2012; 94:1431-6. https:// doi.org/10.1016/j.biochi.2012.03.023.

18. Siegel C, Li J, Liu F, Benashski SE, McCullough LD. miR23a regulation of X-linked inhibitor of apoptosis (XIAP) contributes to sex differences in the response to cerebral ischemia. Proc Natl Acad Sci USA. 2011; 108:11662-7. https://doi.org/10.1073/pnas.1102635108.

19. Huang X, Wu Z, Mei Y, Wu M. XIAP inhibits autophagy via XIAP-Mdm2-p53 signalling. EMBO J. 2013; 32:2204-16. https://doi.org/10.1038/emboj.2013.133.

20. Merlo P, Cecconi F. XIAP: inhibitor of two worlds. EMBO J. 2013; 32:2187-8. https://doi.org/10.1038/emboj.2013.152.

21. Frankel LB, Lund AH. MicroRNA regulation of autophagy. Carcinogenesis. 2012; 33:2018-25. https://doi.org/10.1093/ carcin/bgs266.

22. Tekirdag KA, Korkmaz G, Ozturk DG, Agami R, Gozuacik D. MIR181A regulates starvation- and rapamycin-induced autophagy through targeting of ATG5. Autophagy. 2013; 9:374-85. https://doi.org/10.4161/auto.23117.

23. Korkmaz G, le Sage C, Tekirdag KA, Agami R, Gozuacik D. miR-376b controls starvation and mTOR inhibition-related autophagy by targeting ATG4C and BECN1. Autophagy. 2012; 8:165-76. https://doi.org/10.4161/auto.8.2.18351.

24. Ambros V. The functions of animal microRNAs. Nature. 2004; 431:350-5. https://doi.org/10.1038/nature02871.

25. Russo G, Giordano A. miRNAs: from biogenesis to networks. Methods Mol Biol. 2009; 563:303-52. https:// doi.org/10.1007/978-1-60761-175-2_17.

26. Yang X, Zhong X, Tanyi JL, Shen J, Xu C, Gao P, Zheng TM, DeMichele A, Zhang L. mir-30d Regulates multiple genes in the autophagy pathway and impairs autophagy process in human cancer cells. Biochem Biophys Res Commun. 2013; 431:617-22. https://doi.org/10.1016/j.bbrc.2012.12.083.

27. Korkmaz G, Tekirdag KA, Ozturk DG, Kosar A, Sezerman OU, Gozuacik D. MIR376A is a regulator of starvation-induced autophagy. PLoS One. 2013; 8:e82556. https://doi.org/10.1371/journal.pone.0082556.

28. Yi H, Liang B, Jia J, Liang N, Xu H, Ju G, Ma S, Liu X. Differential roles of miR-199a-5p in radiation-induced autophagy in breast cancer cells. FEBS Lett. 2013; 587:436-43. https://doi.org/10.1016/j.febslet.2012.12.027.
29. Lewis BP, Burge CB, Bartel DP. Conserved seed pairing, often flanked by adenosines, indicates that thousands of human genes are microRNA targets. Cell. 2005; 120:15-20. https://doi.org/10.1016/j.cell.2004.12.035.

30. Liu X, Liu Q, Fan Y, Wang S, Liu X, Zhu L, Liu M, Tang H. Downregulation of PPP2R5E expression by miR-23a suppresses apoptosis to facilitate the growth of gastric cancer cells. FEBS Lett. 2014; 588:3160-9. https://doi. org/10.1016/j.febslet.2014.05.068.

31. Yong FL, Wang CW, Roslani AC, Law CW. The involvement of miR-23a/APAF1 regulation axis in colorectal cancer. Int J Mol Sci. 2014; 15:11713-29. https:// doi.org/10.3390/ijms150711713.

32. Hippert MM, O'Toole PS, Thorburn A. Autophagy in cancer: good, bad, or both? Cancer Res. 2006; 66:9349-51. https://doi.org/10.1158/0008-5472.CAN-06-1597.

33. Bhutia SK, Kegelman TP, Das SK, Azab B, Su ZZ, Lee SG, Sarkar D, Fisher PB. Astrocyte elevated gene-1 induces protective autophagy. Proc Natl Acad Sci USA. 2010; 107:22243-8. https://doi.org/10.1073/pnas.1009479107.

34. Ouyang L, Shi Z, Zhao S, Wang FT, Zhou TT, Liu B, Bao JK. Programmed cell death pathways in cancer: a review of apoptosis, autophagy and programmed necrosis. Cell Prolif. 2012; 45:487-98. https://doi.org/10.1111/j.13652184.2012.00845.x

35. Mortimore GE, Poso AR, Lardeux BR. Mechanism and regulation of protein degradation in liver. Diabetes Metab Rev. 1989; 5:49-70.

36. Blommaart EF, Luiken JJ, Meijer AJ. Autophagic proteolysis: control and specificity. Histochem J. 1997; 29:365-85.

37. Li X, Liu X, Xu W, Zhou P, Gao P, Jiang S, Lobie PE, Zhu T. c-MYC-regulated miR-23a/24-2/27a cluster promotes mammary carcinoma cell invasion and hepatic metastasis by targeting Sprouty2. J Biol Chem. 2013; 288:18121-33. https://doi.org/10.1074/jbc.M113.478560.

38. Petiot A, Ogier-Denis E, Blommaart EF, Meijer AJ, Codogno P. Distinct classes of phosphatidylinositol 3 '-kinases are involved in signaling pathways that control macroautophagy in HT-29 cells. J Biol Chem. 2000; 275:992-8.

39. Seglen PO, Gordon PB. 3-Methyladenine: specific inhibitor of autophagic/lysosomal protein degradation in isolated rat hepatocytes. Proc Natl Acad Sci USA. 1982; 79:1889-92.

40. Ito S, Koshikawa N, Mochizuki S, Takenaga K. 3-Methyladenine suppresses cell migration and invasion of HT1080 fibrosarcoma cells through inhibiting phosphoinositide 3-kinases independently of autophagy inhibition. Int J Oncol. 2007; 31:261-8.

41. Shaw TJ, Lacasse EC, Durkin JP, Vanderhyden BC. Downregulation of XIAP expression in ovarian cancer cells induces cell death in vitro and in vivo. Int J Cancer. 2008; 122:1430-4. https://doi.org/10.1002/ijc.23278. 
42. Dai Y, Qiao L, Chan KW, Zou B, Ma J, Lan HY, Gu Q, Li Z, Wang Y, Wong BL, Wong BC. Loss of XIAP sensitizes rosiglitazone-induced growth inhibition of colon cancer in vivo. Int $\mathrm{J}$ Cancer. 2008; 122:2858-63. https://doi. org/10.1002/ijc.23443.

43. Zhang SG, Ding F, Luo AP, Chen AG, Yu ZC, Ren SH, Liu ZH, Zhang L. XIAP is highly expressed in esophageal cancer and its downregulation by RNAi sensitizes esophageal carcinoma cell lines to chemotherapeutics. Cancer Biology \& Therapy. 2007; 6:973-9.

44. Mizutani Y, Nakanishi H, Li YN, Matsubara H, Yamamoto K, Sato N, Shiraishi T, Nakamura T, Mikami K, Okihara K, Takaha N, Ukimura O, Kawauchi A, et al. Overexpression of XIAP expression in renal cell carcinoma predicts a worse prognosis. Int J Oncol. 2007; 30:919-25.

45. Giagkousiklidis S, Vellanki SH, Debatin KM, Fulda S. Sensitization of pancreatic carcinoma cells for gammairradiation-induced apoptosis by XIAP inhibition. Oncogene. 2007; 26:7006-16. https://doi.org/10.1038/sj.onc.1210502.

46. Aka JA, Lin SX. Comparison of Functional Proteomic Analyses of Human Breast Cancer Cell Lines T47D and MCF7. Plos One. 2012; 7. https://doi.org/10.1371/journal. pone.0031532.

47. Radde BN, Ivanova MM, Mai HX, Salabei JK, Hill BG, Klinge CM. Bioenergetic differences between MCF-7 and T47D breast cancer cells and their regulation by oestradiol and tamoxifen. Biochem J. 2015; 465:49-61. https://doi. org/10.1042/bj20131608.

48. Harlin H, Reffey SB, Duckett CS, Lindsten T, Thompson CB. Characterization of XIAP-deficient mice. Mol Cell Biol. 2001; 21:3604-8. https://doi.org/10.1128/MCB.21.10.36043608.2001 .

49. Wan G, Xie WD, Liu ZY, Xu W, Lao YZ, Huang NN, Cui K, Liao MJ, He J, Jiang YY, Yang BB, Xu HX, Xu NH, et al. Hypoxia-induced MIR155 is a potent autophagy inducer by targeting multiple players in the MTOR pathway. Autophagy. 2014; 10:70-9. https://doi.org/10.4161/ auto.26534.
50. Liu J, Zhu HC, Yang X, Ge YY, Zhang C, Qin Q, Lu J, Zhan LL, Cheng HY, Sun XC. MicroRNA-21 is a novel promising target in cancer radiation therapy. Tumor Biology. 2014; 35:3975-9. https://doi.org/10.1007/s13277014-1623-8.

51. Miller TE, Ghoshal K, Ramaswamy B, Roy S, Datta J, Shapiro CL, Jacob S, Majumder S. MicroRNA-221/222 Confers Tamoxifen Resistance in Breast Cancer by Targeting p27Kip1. Journal of Biological Chemistry. 2008; 283:29897-903. https://doi.org/10.1074/jbc.M804612200.

52. Chen WX, Hu Q, Qiu MT, Zhong SL, Xu JJ, Tang JH, Zhao JH. miR-221/222: promising biomarkers for breast cancer. Tumour Biol. 2013; 34:1361-70. https://doi.org/10.1007/ s13277-013-0750-y.

53. Wu ZS, Wu Q, Wang CQ, Wang XN, Huang J, Zhao JJ, Mao SS, Zhang GH, Xu XC, Zhang N. miR-340 inhibition of breast cancer cell migration and invasion through targeting of oncoprotein c-Met. Cancer. 2011; 117:2842-52. https://doi.org/10.1002/cncr.25860.

54. Wu ZS, Wang CQ, Xiang R, Liu X, Ye S, Yang XQ, Zhang GH, $\mathrm{Xu} \mathrm{XC}, \mathrm{Zhu} \mathrm{T}, \mathrm{Wu}$ Q. Loss of miR-133a expression associated with poor survival of breast cancer and restoration of miR-133a expression inhibited breast cancer cell growth and invasion. BMC Cancer. 2012; 12:51. https://doi.org/10.1186/1471-2407-12-51.

55. Wu ZS, Wu Q, Wang CQ, Wang XN, Wang Y, Zhao JJ, Mao SS, Zhang GH, Zhang N, Xu XC. MiR-339-5p inhibits breast cancer cell migration and invasion in vitro and may be a potential biomarker for breast cancer prognosis. BMC Cancer. 2010; 10: 542. https://doi.org/10.1186/1471-240710-542. 